\title{
Effect of Planting Methods on Agronomic Traits and Forage Yield of Maize (Zea mays $L$.) in Saline Conditions
}

\author{
Saeed Khavari Khorasani ${ }^{1, *}$, Rasoul Banaee ${ }^{2}$ \\ ${ }^{1}$ Seed and Plant Improvement Department, Khorasan Razavi Agricultural and Natural Resources Research and Education Center, \\ AREEO, Mashhad, Iran. \\ ${ }^{2}$ Plant Breeding, Mashhad, Iran.
}

\begin{abstract}
How to cite this paper: Saeed Khavari Khorasani, Rasoul Banaee. (2020) Effect of Planting Methods on Agronomic Traits and Forage Yield of Maize (Zea mays L.) in Saline Conditions. International Journal of the Science of Food and Agriculture, 4(2), 166-173.

DOI: $10.26855 /$ ijfsa.2020.06.008
\end{abstract}

Received: March 22, 2020

Accepted: April 17, 2020

Published: May 18, 2020

"Corresponding author: Saeed Khavari Khorasani, Seed and Plant Improvement Department, Khorasan Razavi Agricultural and Natural Resources Research and Education Center, AREEO, Mashhad, Iran.

Email: khavaris80@yahoo.com

\begin{abstract}
Soil and water salinity is one of the most important limiting factors of plant production, especially in arid and semi-arid areas. Soil is extremely affected by salinity, in a wide range of fields in Iran. The present study was conducted in Abbas-Abad research station, Mashhad, Iran during 2017 growing season. Two planting methods (furrow and ridge planting) and five long-season maize hybrids were studied as a factorial experiment based on a randomized complete block design (RCBD) with four replications. The ear/biomass weight ratio, in each of plots was recorded as forage quality index (FQI). The results of ANOVA showed that the most of studied traits were not affected by interaction between planting method and variety treatments. We observed significant differences among single cross hybrids for quality and also quantity of forage yield and related traits. Means of Fresh and dried biomass weights were 51.18 and 17.31 ton/ha, respectively, in furrow planting compared with 40.66 and 13.79 ton/ha in ridge planting method. Results in furrow planting method indicates the importance of plant establishment, plant and ear heights, leaves number, days to anthesis and days to silking traits in final forage yield production, comparing with ridge planting method. Highest and lowest FQI were recorded 0.39 and 0.18 for KSC703 and KSC715b, respectively. According to screening of hybrids and their parental inbred lines, our results indicated that single cross hybrid KSC706 showed considerable fresh and dried forage yields and could be recommended in maize breeding programs under saline conditions.
\end{abstract}

Keywords

Furrow Planting, Ridge Planting, Forage Quality Index, Zea mays L

\section{Introduction}

More than one billion hectare of lands, are affected by salinity around the world. Globally, plant production adversely affected by salt stress in at least 20 percent of cultivated lands [1]. About 45 million out of 230 million hectares of irrigated farmlands are subjected to salinity. Two million hectare of farmlands are devastated by salinity, yearly [2]. According to FAO, total saline lands in the world, is about 397 million hectare. Africa, Asia, 
Australia, Europe, Latin America, Middle East and North America are highly exposed to Salinity, respectively [3]. Iran is highly subjected to salinity stress and about 12 percent of areas are allocated to plant cultivation which 50 percent of them are exposed to salinity, sodic stress or flooding [4]. Salinity is the presence of dissolved salts and inorganic materials in soil and water which results in salt accumulation in root zone and makes it difficult to absorb water by plant [5]. Cell growth and metabolism affects by high salt content which results in low plant yield [2]. Salinity results in high osmotic pressure and low water absorption. Ion toxicity is the possible consequent of high osmotic pressure [2]. Plant growths and production, reduces at salt concentrations above the salinity threshold [6].

Salt tolerance is the ability of plants to keep growth and yield production at high levels of salt content in root zone and it is evaluated by comparing yield production in saline and non-saline soils. Maize is tolerated to salinity at germination stage but seed germination may postpone by high concentrations of salt. In addition, the vigor indexes of maize seedlings were affected by higher levels $\left(8\right.$ and $12 \mathrm{ds}^{-1} \mathrm{~m}^{-1}$ of salt [7]. Many scientists believed that maize is not suitable plant for saline soils or irrigate by saline water conditions. Farooq et al. [8] declared increase of electrical conductivity (EC) of water for irrigation in maize fields can reduce germination parameters due to osmotic pressure and toxicity of ions in growth environment. Hoffman et al. [9] founded that maize yield production did not affect by salt stress at $3.7 \mathrm{ds} . \mathrm{m}^{-1}$, but at higher levels of salinity, 14 percent yield decrement per unit of increase in EC, was observed due to reduce in plant density and grain gravity. Kaddah and Malek [10] investigated on the effect of different levels of salinity on maize growth. They declared that salt tolerance can be increased in late growth stages and the impact of salinity on grain yield was more severe than forage yield. Alius et al. [11] concluded that at all maize genotypes high salinity of $200,400 \mathrm{mM}$ of both $\mathrm{NaCl}$ and $\mathrm{CaCl} 2$ caused decrease in seed germination. Hybrid genotypes and local maize populations treated by $400 \mathrm{mM}$ showed significantly lower germination ability. Kaya et al. [12] studied maize seedlings were subjected to $\mathrm{NaCl}$ in greenhouse and were sprayed by asparagines and glycerol after germination. The results showed that glycerol was more effective than asparagines in improving salinity tolerance of maize plants in terms of growth and some of physiological traits. Meijie et al. [13] compared the seedling root proteomes of salt-tolerant Jing724 and salt-sensitive D9H maize genotypes underlying salt tolerance. They found that germination rate and growth parameter values (weight and length) were higher for Jing724 than for D9H under saline conditions. They identified 513 differentially regulated proteins (DRPs). In salt-stressed Jing724, the DRPs were primarily associated with the pentose phosphate pathway, glutathione metabolism, and nitrogen metabolism.

Soufan and Okla [14] showed that maize variety Ghota-1 could tolerate water salinity stress up to $4 \mathrm{~g} / \mathrm{L}$ of sodium chloride, while all morphological and productivity characteristics were affected. Accodrding to Emdad and Fardad [15], and Yu et al. [16] plant height significanlty decreased by salinity. Molazem et al.[17] and Molazem and Bashirzadeh [32] reported that different maize cultivars, show different response to salinity. The highest soduim accumulation observed for cultivar KSC704, at saline conditon. Khavari et al. [7] studied the response of 46 maize genotypes under saline condition at Mashhad, Iran. The results showed unfavorable effects of salt stress on maize genotypes, especially inbred lines. The single cross hybrid KE72012/1-12 × K2331 with $7.77 \mathrm{ton} / \mathrm{ha}$ and inbred line KE72012/1-12 with 1.722 ton/ha had the highest grain yield. Zarandi et al. [18] evaluated 27 single cross maize hybrids in field under saline $\left(\mathrm{EC}=8.5 \mathrm{ds} . \mathrm{m}^{-1}\right)$ and normal conditions. The result showed that hybrids $\mathrm{BC} 282$, KSC350 and ZP341 had the highest grain yield both in normal and salt stress conditions.

Uddin et al. [19] evaluated a series of experiments in both greenhouse and field. They evaluated 290 Test-crossed hybrids at green house under hydroponic culture for salinity, drought, water logged and low-phosphorus stresses at seedling stage, in six different field locations in Bangladesh - including saline and drought - and with six popular commercial checks. Hossain et al. [20] studied 45 testcrosses hybrids maize for phenotyping of salt stress tolerant in hydroponic culture at greenhouse on Bangladesh. Through analysis it was concluded that P-16 x IPB911-16 was the most salt tolerant genotype, while very susceptible genotypes were CZI-26 x IPB911-16. Appropriate planting pattern results to higher radiation use efficiency due to proper light distribution in the canopy. Planting salt tolerate crops is the most suitable way to benefit saline soils, because soil reclamation is time consuming and unaffordable [21]. Maize is moderately sensitive to salinity [9], thus diminishing salinity effects on yield reduction, are the best way in facing salt stress [22].

Identifying the most appropriate planting method is a key step to higher yield production per unit area, under 
saline condition [23]. The accessibility of plants to light, water and soil nutrition is affected by planting method [24]. Recently studies are about different effects of single and double rows ridge planting in non-stress condition. Planting methods in saline condition have to be different by those of non-stress conditions. Furrow planting is suggested as a proper way of facing salinity. Furrow planting, results in leaching and makes a salt free zone close to the roots. It results in less lodging due to high aerial root production in maize. Grain yield was higher in double rows on ridge compared with single row, due to low salt accumulation on ridge-sides and higher water accessibility [25].

The aim of the present study is to investigate the effect of different planting methods on forage yields of maize hybrids under saline conditions.

\section{Materials and Methods}

This study was conducted in Abbas-Abad animal research center, during 2017 growing season. The research station is located in Tangalshur, Mashhad, Iran, with $36^{\circ} 16 \mathrm{~N}$ latitude and $59^{\circ} 38 \mathrm{E}$ longitudes, $985 \mathrm{~m}$ altitude above the sea level. Electrical conductivity (EC) of water and soil were 5 and $4.95 \mathrm{ds}^{-1} \mathrm{~m}^{-1}$, respectively. Two planting methods (furrow and ridge planting) and five long-season maize cultivars [four commercial single cross hybrids (KSC703, KSC704, KSC705, KSC706) and a promising hybrid (KSC715b)] were studied as a factorial experiment based on a randomized complete block design (RCBD), with four replications. These single cross hybrids are released from a classic breeding program in seed and plant improvement institute (SPII), Karaj, Iran. The origin of breeding materials is from CIMMYT temperate populations.

In order to preparing the soil, the first plowing was done deeply, in the autumn. The field was ploughed again, just before planting, in the spring and finally disk harrowed. Planting was done by June 7 th. Each plot was of $6 \mathrm{~m}$ in length and $2.5 \mathrm{~m}$ width including plant stand (intra row: $75 \mathrm{~cm}$, inter row: $15 \mathrm{~cm}$ ). Drip tapes were placed beside the seedlings in furrow planting method, and in the middle of each ridge, for ridge planting. Growing operations like irrigation, fertilization and weed management were performed at proper time. The variations of soil electrical conductivity (EC), was measured during growing season in two stages of plant growth. Soil samples were taken from both furrow and ridges in the field. The phenological traits [Anthesis time, silking time, anthesis-silking interval (ASI) and days to dough stage] were recorded based on 50 percent of trait performance in plots. Agro-Morphological characteristics consisted of plant height, ear height, tassel length, leaves number per plant, leaves number above ear and stalk diameter were measured on 10 randomly competitive plants in each plots. At harvest time, in each plots total plant number were counted and all plants were cut near the ground and ear and biomass weighted, separately. Then, 6 random plants of each plot were selected to determine fresh and dry forage yield. Samples were weighted and then oven dried in $80^{\circ} \mathrm{C}$ for 72 hours. The yield components consisted of ear length, ear diameter, rows number per ear and kernel number per row were measured on 10 random ears in each plot. Ear weight/biomass weight ratio, was considered as forage quality index (FQI). Generally, in non-stress condition, ear/biomass weight ratio should be more than 30 percent to be acceptable forage quality. Comparison of means was conducted using Duncan's multiple range tests. Data were analyzed, using SAS ver. 9.1.

\section{Results and Discussions}

Analysis of variance showed that, seedling establishment percentage, days to anthesis, days to silking, anthesis silking interval (ASI), Leaf number per plant, ear height, plant height, stalk diameter, fresh and dry forage yields were significantly affected by different planting methods (Table 1). Results also indicated significant differences among treatments in respect of days to anthesis, ear length, ear diameter, kernel number per row, leaf number, ear height, tassel length, stalk diameter, ear per plant, FQI and dry forage yield. We found that apart days to silking, ASI and FQI, other studied traits were not significantly affected by interaction between planting methods and treatments (Table 1). 
Table 1. Analysis of variance of forage yield and its components on different maize hybrids under saline condition

\begin{tabular}{|c|c|c|c|c|c|c|c|c|c|c|}
\hline \multirow[b]{2}{*}{ S.O.V } & \multirow[b]{2}{*}{ d.f } & \multicolumn{9}{|c|}{ Mean squares } \\
\hline & & $\begin{array}{c}\text { Plant } \\
\text { Establishment \% }\end{array}$ & $\begin{array}{l}\text { Days to } \\
\text { anthesis }\end{array}$ & $\begin{array}{l}\text { Days to } \\
\text { silking }\end{array}$ & ASI & $\begin{array}{l}\text { Ear } \\
\text { length }\end{array}$ & $\begin{array}{c}\text { Ear } \\
\text { diameter }\end{array}$ & $\begin{array}{l}\text { Row } \\
\text { per ear }\end{array}$ & $\begin{array}{l}\text { Kernel } \\
\text { per row }\end{array}$ & $\begin{array}{l}\text { Leaf } \\
\text { number }\end{array}$ \\
\hline Replication & 3 & $498.77^{* *}$ & $17.50^{* *}$ & $27.90^{* *}$ & $1.80^{\mathrm{ns}}$ & $3.09 \mathrm{~ns}$ & $9.40^{\mathrm{ns}}$ & $7.40^{\mathrm{ns}}$ & $42.25^{\mathrm{ns}}$ & $0.74^{*}$ \\
\hline Planting pattern & 1 & $6068.59^{* *}$ & $14.40^{* *}$ & $32.40^{* *}$ & $3.60^{*}$ & $1.85^{\mathrm{ns}}$ & $2.03^{\mathrm{ns}}$ & $1.33^{\mathrm{ns}}$ & $0.68^{\mathrm{ns}}$ & $1.07^{*}$ \\
\hline Cultivars & 4 & $114.69^{\mathrm{ns}}$ & $4.73^{*}$ & $5.09^{\mathrm{ns}}$ & $1.71^{\mathrm{ns}}$ & $47.22^{* *}$ & $57.37^{* *}$ & $16.34^{\mathrm{ns}}$ & $419.99^{* *}$ & $1.27^{* *}$ \\
\hline $\begin{array}{c}\text { Planting pattern } \\
\times \text { hybrid }\end{array}$ & 4 & $21.81^{\mathrm{ns}}$ & $2.78^{\mathrm{ns}}$ & $6.46^{*}$ & $2.04^{*}$ & 0.23 ns & $20.81^{\mathrm{ns}}$ & $10.18^{\mathrm{ns}}$ & $1.78^{\mathrm{ns}}$ & $0.07^{\mathrm{ns}}$ \\
\hline error & 27 & 108.19 & 1.30 & 1.96 & 0.65 & 2.40 & 12.93 & 7.54 & 20.98 & 0.20 \\
\hline C.V \% & & 12.64 & 1.72 & 2.02 & 6.04 & 11.90 & 8.62 & 18.03 & 16.78 & 3.22 \\
\hline
\end{tabular}

Table 1, continued

\begin{tabular}{cccccccccc}
\hline & & \multicolumn{1}{c}{ Mean squares } \\
\cline { 3 - 9 } S.O.V & d.f & Ear height & Plant height & $\begin{array}{c}\text { Tassel } \\
\text { length }\end{array}$ & $\begin{array}{c}\text { Stalk } \\
\text { diameter }\end{array}$ & $\begin{array}{c}\text { Ear per } \\
\text { plant }\end{array}$ & $\begin{array}{c}\text { Forage } \\
\text { quality } \\
\text { index }\end{array}$ & $\begin{array}{c}\text { Fresh forage Dry forage } \\
\text { yield }\end{array}$ \\
yield
\end{tabular}

**, ${ }^{*}$ and $\mathrm{n} . \mathrm{s}$ significant at $1 \%$ and $5 \%$ and not significant, respectively.

Duncan's multiple range tests showed 51.5 and 17.3 ton/ha for fresh and dry forage yields, respectively, in furrow planting method and 40.6 and 13.7 ton/ha fresh and dry forage yields, respectively, in ridge planting method. Higher performance of furrow planting method in forage yields may be the result of better plant establishment (Fig 1), higher plant and ear height, date of anthesis, date of silking and more leaf production of plants in this method compare with ridge planting (Table 2).
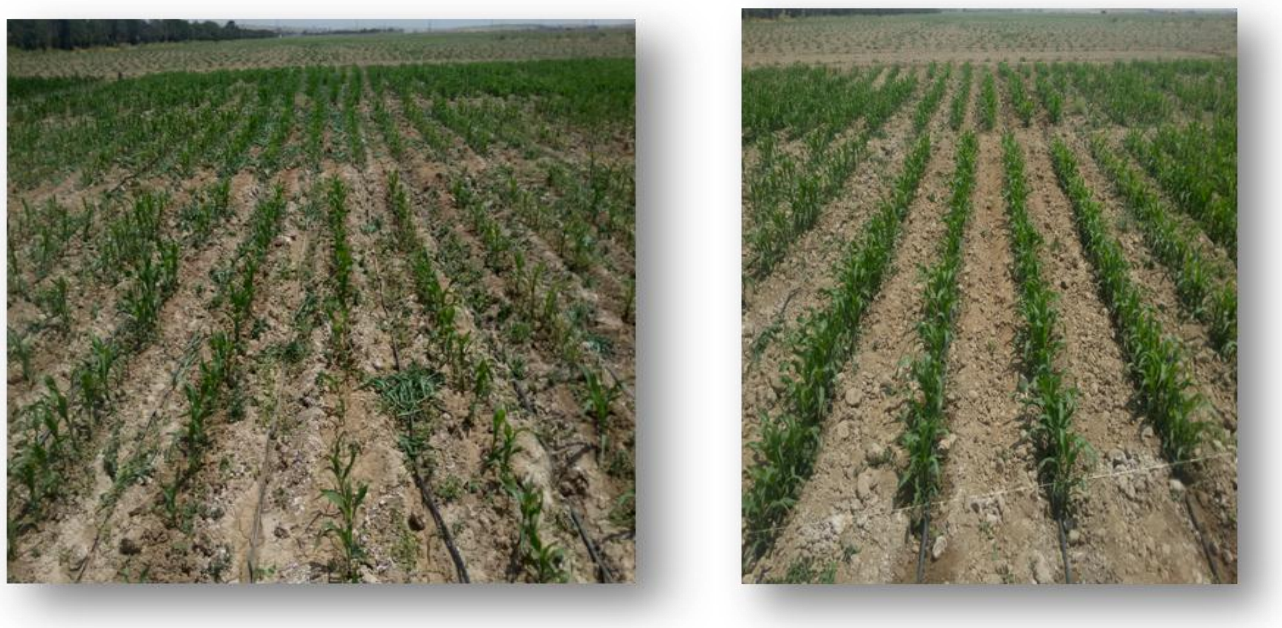

Fig 1. Plant establishment as affected by planting method under saline condition, furrow planting (right) and ridge planting (left). 
Table 2. Studied characteristics as affected by planting method, under saline condition

\begin{tabular}{|c|c|c|c|c|c|c|c|c|c|}
\hline Planting method & $\begin{array}{c}\text { Establishment } \\
(\%)\end{array}$ & $\begin{array}{l}\text { Days to } \\
\text { anthesis }\end{array}$ & $\begin{array}{l}\text { Days to } \\
\text { silking }\end{array}$ & $\begin{array}{l}\text { Anthesis } \\
\text { silking } \\
\text { interval }\end{array}$ & $\begin{array}{l}\text { Ear } \\
\text { length }\end{array}$ & $\begin{array}{c}\text { Ear } \\
\text { diameter }\end{array}$ & $\begin{array}{c}\text { Row per } \\
\text { ear }\end{array}$ & $\begin{array}{l}\text { Kernel } \\
\text { per row }\end{array}$ & $\begin{array}{l}\text { Leaf } \\
\text { number }\end{array}$ \\
\hline Ridge planting & $70.00 \mathrm{~b}$ & $65.45 \mathrm{~b}$ & $68.25 \mathrm{~b}$ & $2.80 \mathrm{~b}$ & $13.23 \mathrm{a}$ & $41.53 \mathrm{a}$ & $15.41 \mathrm{a}$ & $27.43 \mathrm{a}$ & $13.61 \mathrm{~b}$ \\
\hline Furrow planting & $94.63 \mathrm{a}$ & $66.65 \mathrm{a}$ & $70.05 \mathrm{a}$ & $3.40 \mathrm{a}$ & $12.80 \mathrm{a}$ & $41.98 \mathrm{a}$ & $15.05 \mathrm{a}$ & $27.17 \mathrm{a}$ & $13.93 \mathrm{a}$ \\
\hline
\end{tabular}

Table 2, continued

\begin{tabular}{|c|c|c|c|c|c|c|c|c|}
\hline Planting method & $\begin{array}{l}\text { Ear } \\
\text { height }\end{array}$ & Plant height & $\begin{array}{l}\text { Tassel } \\
\text { length }\end{array}$ & $\begin{array}{c}\text { Stalk } \\
\text { diameter }\end{array}$ & $\begin{array}{c}\text { Ear per } \\
\text { plant }\end{array}$ & $\begin{array}{l}\text { Forage quality } \\
\text { index }\end{array}$ & $\begin{array}{c}\text { Fresh forage } \\
\text { yield }\end{array}$ & $\begin{array}{l}\text { Dry forage } \\
\text { yield }\end{array}$ \\
\hline Ridge planting & $74.62 \mathrm{~b}$ & $165.46 \mathrm{~b}$ & $32.58 \mathrm{a}$ & $25.63 \mathrm{a}$ & $1.02 \mathrm{a}$ & $0.34 \mathrm{a}$ & $40.66 \mathrm{~b}$ & $13.79 \mathrm{~b}$ \\
\hline Furrow planting & $90.06 \mathrm{a}$ & $184.85 \mathrm{a}$ & $30.72 \mathrm{a}$ & $23.49 \mathrm{~b}$ & $0.99 \mathrm{a}$ & $0.33 \mathrm{a}$ & $51.158 \mathrm{a}$ & $17.31 \mathrm{a}$ \\
\hline
\end{tabular}

In each column, values that followed by common letters are not significantly different at $5 \%$ level.

The highest leaf number $(13.93)$, ear height $(90.06 \mathrm{~cm})$, plant height $(184.8 \mathrm{~cm})$, plant establishment $(94 \%)$, days to anthesis (66.6), days to silking (70.05), ASI (3.4), ear diameter (41.9 mm) were recorded for furrow planting method (Table 2). Yazdi-Motlagh et al. [26] reported a higher number of days to anthesis, in furrow planting, which was in agreement with the results of present study. Benlloch et al. [27] concluded a low plant establishment under saline condition due to salt accumulation on ridges. Hasan-Zadeh and Basafa [28], Benlloch et al. [27], Zarandi et al. [18], Soufan and Okla [14], reported a significant decrease in yield production under saline condition due to salt accumulation and also the higher ear length and ear diameter in furrow planting method compared with ridge planting [28]. The highest values in ear length $(13.2 \mathrm{~cm})$, rows number per ear (15.4), kernel number per ear $(27.4)$, tassel length $(32.5 \mathrm{~cm})$, stalk diameter $(25.6 \mathrm{~mm})$, ear number per plant $(1.02)$ and FQI (0.34) were measured by ridge planting methods (Table 2). Nasrolah-Alhoseini et al. [29], stated that the highest stalk diameter produced by furrow planting that was opposed to the results of present study. Different environmental conditions of experimental sites and different experimental materials especially soil and water quality, cultivars etc., are possible reasons of disagreement between our results and former ones. Najafi- Nezhad and Farzam-Nia [30] stated that ear and plant height were higher in furrow planting compared with single and double- row on ridge planting methods. According to Tanveer et al. [31], ear production per unit area, ear length, and kernel number per ear were significantly higher in furrow planting of wheat, compared with flat plot planting method. They declared that furrow planting is a suitable method for fields with poor drainage, saline soils and drought conditions. Thus, screening of genotypes (inbred lines or hybrids) with higher forage yields under saline condition is necessary.

Duncan's multiple range tests in respect of treatments showed that the highest fresh (49.97 ton/ha) and dry (17.07 ton/ha) forage yields, produced by hybrid single cross KSC706 with the lowest ASI (2.6) (Table 3).

Table 3. Studied characteristics as affected cultivars, under saline condition

\begin{tabular}{cccccccccc}
\hline cultivar & $\begin{array}{c}\text { Plant } \\
\text { Establishment } \\
\%\end{array}$ & $\begin{array}{c}\text { Days to } \\
\text { anthesis }\end{array}$ & $\begin{array}{c}\text { Days to } \\
\text { silking }\end{array}$ & ASI & $\begin{array}{c}\text { Ear } \\
\text { length }\end{array}$ & Ear diameter & $\begin{array}{c}\text { Row per } \\
\text { ear }\end{array}$ & $\begin{array}{c}\text { Kernel per } \\
\text { row }\end{array}$ & $\begin{array}{c}\text { Leaf } \\
\text { number }\end{array}$ \\
\hline KSC703 & $82.77 \mathrm{a}$ & $67.25 \mathrm{a}$ & $70.00 \mathrm{a}$ & $2.75 \mathrm{~b}$ & $14.94 \mathrm{a}$ & $43.70 \mathrm{ab}$ & $16.96 \mathrm{a}$ & $33.16 \mathrm{a}$ & $13.59 \mathrm{bc}$ \\
$\mathrm{KSC704}$ & $81.86 \mathrm{a}$ & $65.88 \mathrm{~b}$ & $69.63 \mathrm{ab}$ & $3.75 \mathrm{a}$ & $13.35 \mathrm{ab}$ & $40.28 \mathrm{bc}$ & $14.15 \mathrm{ab}$ & $27.69 \mathrm{~b}$ & $13.94 \mathrm{ab}$ \\
KSC705 & $86.13 \mathrm{a}$ & $65.13 \mathrm{~b}$ & $6813 \mathrm{~b}$ & $3.00 \mathrm{ab}$ & $12.84 \mathrm{~b}$ & $45.40 \mathrm{a}$ & $15.41 \mathrm{ab}$ & $28.38 \mathrm{ab}$ & $13.18 \mathrm{c}$ \\
KSC706 & $84.61 \mathrm{a}$ & $65.88 \mathrm{~b}$ & $68.50 \mathrm{ab}$ & $2.63 \mathrm{~b}$ & $14.93 \mathrm{a}$ & $40.35 \mathrm{bc}$ & $16.15 \mathrm{ab}$ & $32.23 \mathrm{ab}$ & $13.94 \mathrm{ab}$ \\
KSC715b & $76.22 \mathrm{a}$ & $66.13 \mathrm{ab}$ & $69.50 \mathrm{ab}$ & $3.38 \mathrm{ab}$ & $9.00 \mathrm{c}$ & $39.03 \mathrm{c}$ & $13.46 \mathrm{~b}$ & $15.05 \mathrm{c}$ & $14.21 \mathrm{a}$ \\
\hline
\end{tabular}


Table 3, continued

\begin{tabular}{ccccccccc}
\hline cultivar & Ear height & Plant height & $\begin{array}{c}\text { Tassel } \\
\text { length }\end{array}$ & $\begin{array}{c}\text { Stalk } \\
\text { diameter }\end{array}$ & $\begin{array}{c}\text { Ear per } \\
\text { plant }\end{array}$ & $\begin{array}{c}\text { Forage } \\
\text { quality index }\end{array}$ & $\begin{array}{c}\text { Fresh } \\
\text { forage } \\
\text { yield }\end{array}$ & $\begin{array}{c}\text { Dried forage } \\
\text { yield }\end{array}$ \\
\hline KSC703 & $82.39 \mathrm{~b}$ & $178.50 \mathrm{~b}$ & $30.46 \mathrm{bc}$ & $23.80 \mathrm{bc}$ & $0.91 \mathrm{bc}$ & $0.39 \mathrm{a}$ & $41.53 \mathrm{~b}$ & $13.18 \mathrm{~b}$ \\
KSC704 & $90.30 \mathrm{a}$ & $189.19 \mathrm{a}$ & $38.86 \mathrm{a}$ & $24.39 \mathrm{bc}$ & $0.89 \mathrm{c}$ & $0.36 \mathrm{a}$ & $46.60 \mathrm{ab}$ & $17.02 \mathrm{a}$ \\
KSC705 & $84.21 \mathrm{ab}$ & $170.80 \mathrm{bc}$ & $33.18 \mathrm{~b}$ & $23.59 \mathrm{c}$ & $0.90 \mathrm{bc}$ & $0.38 \mathrm{a}$ & $44.15 \mathrm{ab}$ & $15.46 \mathrm{ab}$ \\
KSC706 & $86.81 \mathrm{ab}$ & $169.88 \mathrm{bc}$ & $28.63 \mathrm{bc}$ & $25.11 \mathrm{ab}$ & $1.04 \mathrm{~b}$ & $0.38 \mathrm{a}$ & $49.97 \mathrm{a}$ & $17.07 \mathrm{a}$ \\
KSC715b & $67.98 \mathrm{c}$ & $167.39 \mathrm{c}$ & $27.11 \mathrm{c}$ & $25.90 \mathrm{a}$ & $1.28 \mathrm{a}$ & $0.18 \mathrm{~b}$ & $47.37 \mathrm{ab}$ & $15.02 \mathrm{ab}$ \\
\hline
\end{tabular}

In each column, values that followed by common letters are not significantly different at $5 \%$ level.

Results also indicate that there was no significant difference among KSC704, KSC705 and KSC715b, in respect of fresh forage yield. The highest days to anthesis (67.2), days to silking (70), ear length $(14.9 \mathrm{~cm})$, rows number per ear (16.9), kernel number per ear (33.1) and FQI (0.39) produced by KSC703. The highest amounts of ASI (3.7), ear height $(90.3 \mathrm{~cm})$, plant height $(189.1 \mathrm{~cm})$ and tassel length $(38.8 \mathrm{~cm})$; and the lowest ear number per plant (0.89), belongs to KSC704. The highest plant establishment (86.1\%), ear diameter (45.4 $\mathrm{mm})$ and the lowest days to anthesis (65) and silking (68), leaf number per plant (13.1) and stalk diameter (23.5 mm) produced by KSC705 (table 3). KSC715b showed the lowest ear length $(9 \mathrm{~cm})$, ear diameter $(39.3 \mathrm{~mm})$, rows number per ear (13.4), kernel number per row (15), ear height $(67.9 \mathrm{~cm})$, plant height $(167.3 \mathrm{~cm})$, FQI $(0.18 \%)$ and tassel length $(27.1 \mathrm{~cm})$ and the highest values for leaf number $(14.2)$, stalk diameter $(25.9 \mathrm{~mm})$ and ear number per plant (1.28). Low forage quality index (FQI) of KSC715b may be result of low yield component production and poor plant establishment (76\%), under saline condition (Fig. 2). The results were in agreement with Nasrolah-Alhoseini et al. [29], Yazdi-Motlagh et al. [26], Molazem and Bashirzadeh [32] and Najafi-Nezhad and Farzam-Nia [30].
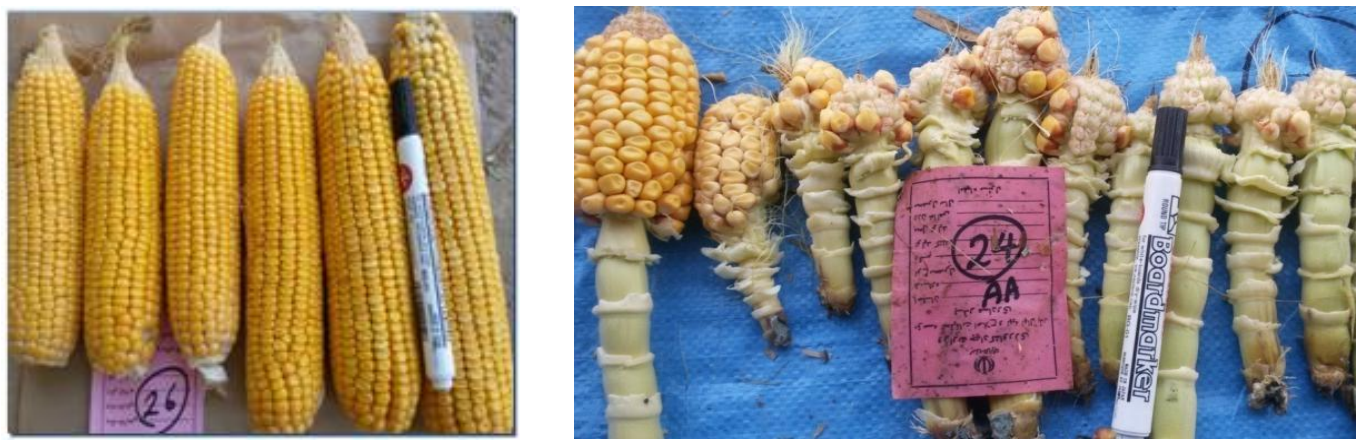

Fig 2. Response of tolerate (KSC705)(left) and sensitive (KSC715b)(right)maize hybrids to salinity.

\section{Conclusion}

Under saline condition, furrow planting has various benefits compared with ridge planting methods which results in better crop production. In the present study, higher forage yield produced by furrow planting due to better plant establishment, higher plant and ear heights, and better anthesis and pollination compared with ridge planting. The highest fresh and dry forage yield, produced by KSC706 under saline condition. Decreased forage quality index (FQI) under saline condition is expectable. Thus, the highest (0.39) and lowest (0.18) of FQI were recorded for KSC703 and $\mathrm{KSC} 715 \mathrm{~b}$, respectively. It is necessary to screen maize cultivars in order to recommend potentially salt tolerant hybrids that are suitable for saline condition and breeding programs.

\section{References}

[1] Tuteja, N. (2007). "Mechanisms of High Salinity Tolerance in Plants.” Methods in Enzymology 428: 419-436.

[2] Munns R, and Tester, M. (2008). Mechanisms of salinity tolerance. Ann Rev Plant Biol 59:651-681.

[3] Allbed, A. and Kumar, L. (2013). Soil Salinity Mapping and Monitoring in Arid and Semi-Arid Regions Using Remote Sensing Technology: A Review. Advances in Remote Sensing, 02(04). p: 373-385. 
[4] Afiuni, D. and Marjooie, A.R. (2009). Assessment of different bread wheat cultivars responses to irrigation water salinity. Journal of Crops Improvement. 11(2). P: 1-10.

[5] Grieve, C. M., and Shannon. M. C. (1999). "Ion accumulation and distribution in shoot components of salt-stressed Eucalyptus clones.” Journal of the American Society for Horticultural Science 124.5 (1999): 559-563.

[6] Ranjbar, G.H. and Banakar, M.H. (2011). Salt Tolerance Threshold of Four Commercial Wheat (Triticum Aestivum L.) Cultivars. Iranian Journal of Soil Research (Formerly Soil and Water science). 24(3). P: 237-242.

[7] Khavari khorasani, S., Khazaee, H., and Mohammadi, M. 2017. Evaluation of maize (Zea mays L.) genotypes for salt tolerance. Asian Journal of Biological and Life Science. Vol 6 (1).

[8] Farooq M., Hussain M., Wakeel A., Kadambot H. and Siddique, M. (2015). Salt Stress in Maize: Effects, Resistance Mechanisms and Management. A review. 35(2):461-481.

[9] Hoffman, G. J. Maas, E.V. Prichard, T. L. Meyer, J. L. and Roberts, R. (1983). Salt toleance of corn in the Sacramento-Sanjoaquin delta of California. Irrigation Science. 4:1, 31-44.

[10] Kaddah, F., and Malek, T. (1961). Salinity effects on the growth of corn at different stages of development. Agronomy Journal. 56(2). p: 214-217.

[11] Alius S., Rusinovci I., Gashi B., Shala-MayrhoferV., Fetahu S., Elezi F., and Lemmens M. (2015). The effects of salt stress on seed germination of some maize (Zea mays L.) genotypes. 50th Croatian and 10th International Symposium on Agriculture. Opatija . Croatia (299-303).

[12] Kaya, C., Aydemir, S., Sonmez, O., Ashraf, M., and Dikilitas, M. (2013). Regulation of growth and some key physiological processes in salt-stressed maize (Zea mays L.) plants by exogenous application of asparagine and glycerol. Acta Botanica Croatica, 72(1), 157-168.

[13] Meijie L., Yanxin Z., Yuandong W., Zi S., Panpan Z., Yunxia Z., Wei S., and Jiuran Z. (2018). Comparative Proteomics of Contrasting Maize Genotypes Provides Insights into Salt-Stress Tolerance Mechanisms. Journal of Proteome Research. Vol 17(1). Pp: 141-153

[14] Soufan W., and Okla M.K. (2014). Effect of salt stress on germination, growth and yield of maize (Zea mays L. CV. Ghota-1). Journal of Pure and Applied Microbiology 8(1):185-194

[15] Emdad, M. R. and Fardad, H. (2000). Effect of Salt and Water stress on corn yield production. Iranian Journal of Agriculture Science. 31(3). Pp: 641-654.

[16] Yu, X., Liao, Y. and Oladipo, I.O. (2014). Effect of salinity water irrigation on maize growth in northwest region. Journal of Chemical and Pharmaceutical Research. 6(1). p:300-305.2014.

[17] Molazem, D. Azimi J., Ghasemi M. and Khatami A. (2013). Growth and accumulation of sodium in some genotypes of maize (Zea mays $L$ ) under salt stress and evaluate the correlation between them. Life Science Journal. 10(1).p:21-25.

[18]Zarandi, S., Chokan, R., and Bihamta, M.R. (2008). Response of commercial grain maize hybrids to salt stress. The 10th National Genetics Congress, Iran Medical Science University, Tehran, Iran, 10-14 June, 2008.

[19] Uddin, M. S., Begum F., Rohman M.M., Hossain M.G., Ahmed A., Ahmed M., Billah M., Hossain N., Akther S., Bagum S.A., Rahman M.A., Sarker M.B., Hossain M.I., Azam M.G., Hakim M.A., Barma N.C.D. and Amiruzzaman M. (2018). Development of Multiple Abiotic Stress Tolerance Hybrid Maize for Climate Smart Agriculture. 13th Asian Maize Conference and Expert Consultation on Maize for Food, Feed, Nutrition and Environmental Security, Ludhiana, India October 8-10, 2018.

[20] Hossain, N., Hasanuzzaman, M. Billah, M. Akter, S.Bagum S.A. and Uddin., M.S. (2018). Phenotyping of Hybrid Maize Through Hydroponic Culture at Seedling Stage under Salt Stress. 13th Asian Maize Conference and Expert Consultation on Maize for Food, Feed, Nutrition and Environmental Security, Ludhiana, India October 8-10, 2018.

[21] Princ, G.M. (1969). Grain yield of corn and grain sorghum under different plant population and row spacing. Soil Crop Science 29:181-189.

[22] Ahmad, P., and Prasad, M.N.V. (2012). Abiotic Stress Responses in Plants Metabolism, Productivity and Sustainability. New York, Springer.

[23] Emam, Y., and Seghatelestami, M.J. (2005). Crop Yield. Physiology and Processes. Shiraz Univ. Press. 593p.

[24] Ashraf, M. and Rauf, H. (2001). Inducing salt tolerance in maize Zea mays L. through seed priming with chloride salts: growth and ion transport at early growth stages. ActaPhysiologiae Planetarium, 23: 407-414. 
[25] Barzegari, M. (2006). Planting corn in Furrow on light, saline and sandy soils. Safi Abad Agricultural Research Center, Dezful, Khouzestan., The final report of the research project.

[26] Yazdi- Motlagh, A., Khavari- Khorasani, S., Bakhtiari, S., and Musa-Abadi, J. (2012). Effect of planting pattern on Morphophysiologic characteristics, yield and yield components of forage maize varieties (Zea mays L.) in saline conditions. J. Agr. Ecol., 4: 324-327.

[27] Benlloch, M., Ojeda, M.A., Ramos, J., and Rodriguez-Navarro, A. (1994). Salt sensivity and low discrimination between potassium and sodium in bean plants. Plant and Soil. 166: 117-123.

[28] Hasanzadeh, H., and Basafa, M. (2006). Study the effect of planting method and density plant on forage yield of corn in saline conditions. The $9^{\text {th }}$ Conference of Agronomy and Plant Breeding Sciences Iran.

[29] Nasrolah Alhoseini, S.M., Zekri, S., and Nabavi Kalat, S.M. (2009). Study of saline stress on germination traits of three sweet corn varieties. In First Environmental Stresses National Conference in Agricultural Sciences 27-30 February, Birajand University, Iran.

[30] Najafi-Nejad, H., and Farzam-Nia, M. (2006). Effect planting pattern on yield, agronomic characteristics and water use efficiency of two cultivar of maize (SC700 and SC704). The proceeding of the 9th Iranian crop science congress. page 205.

[31] Tanveer, S.K., Hussain, I., Sohail, M., Kissan, N.S., and Abbas, S.G. (2003). Effects of different planting methods on yield and yield components of wheat. Asian Journal of Plant Sciences. 811- 813.

[32] Molazem, D. and Bashirzadeh, A. (2015). Morpho-Physiological Characterization in Eight Varieties of Maize (Zea mays L.) under Soil Salinity Polish. Journal of Environmental Studies. Vol. 24(6). Pp: 2537-2542. 